\title{
A Reflection on Classes; a Reflection on Parties
}

\begin{abstract}
This chapter proposes a reflection on classes, on parties and on the relationship between the two. In order to analyse the class basis of social democracy, the first step is to take sociology seriously. The challenge is to define social class and work with a class schema that captures important divisions in the labour market. The second step is to take politics seriously. Social class becomes a useful category for political analysis when one includes the crucial role of political actors in class mobilisation. The third step involves taking history seriously in order to precisely draw the contours of a working-class party. The challenge is to avoid the serious pitfalls of over-estimating or under-estimating the working-class character of social democracy. After having taken these three steps, the chapter concludes with a description of the Oesch class schema used in this book.
\end{abstract}

Keywords Social class · Working-class party · Labour movement

L. Rennwald, Social Democratic Parties and the Working Class, Challenges to Democracy in the 21st Century, https://doi.org/10.1007/978-3-030-46239-0_2 


\section{TAKing Sociology Seriously: Social Class to Capture Important DiffERENCES IN THE LABOUR MARKET}

The existence of various definitions of the working class and controversies about the concept of social class itself represent substantial challenges in an analysis of the class basis of social democracy. Moreover, there is a tendency among large parts of the scientific community (and also among the broader public) to reject the concept of social class on the ground that it belongs to a Marxist framework of analysis - which today is often rejected in mainstream social science research. Scholars increasingly use income categories or discuss differences in education levels. However, it must be clarified that one does not need to be a Marxist to use social class and to analyse social stratification. Not only Karl Marx but also his bourgeois critic Max Weber widely used social class in their writings. Quantitative empirical research is also relatively pragmatic. Erikson and Goldthorpe (1992: 35ff), who developed one of the most important class schemata used in empirical research, consider their schema an 'instrument de travail' and rely on elements from both Marx and Weber. Moreover, occupation represents a central indicator in all class schemata.

This book chooses to talk about social classes in order to analyse the relationship between social democracy and workers. In the European context, the dominance of the industrial sector has created unique configurations of linkages between political parties and social classes (Therborn 1995: 68). Parties have developed around specific classes, and not around specific income groups or education levels (even if the two are, of course, related). Liberal and conservative parties were created to represent the interests of the bourgeoisie, and the socialist parties emerged to represent the interests of the working class in the political arena. Needless to say, perhaps, a focus on income would ignore one of the most important dividing lines in history, the one between workers and employers/the self-employed.

I belong to a tradition in sociology that stresses the 'objective' component of social class (class in itself). In practice, it is possible to allocate a class position to individuals on the basis of their positions in the labour market and to empirically analyse the effects of inequalities among the positions of individuals. Class is a way to capture important differences in material conditions and economic interests. Sociologists have developed complex class schemata where individuals are allocated a class position 
based on their occupation and their employment status (e.g. Erikson and Goldthorpe 1992; Oesch 2006). The theoretical bases of class schemata vary, but common categories include workers, employers and the selfemployed together with finer distinctions within middle-class employees (managers, professionals, etc.).

Crucially, sociologists can demonstrate that differences among occupational classes do matter. A class schema-if it correctly captures important divisions in the labour market-determines a large range of outcomes, such as the risk of unemployment, income, promotion prospects and social protection (e.g. Goldthorpe and McKnight 2006; Evans and Mills 2000; Oesch 2006). The crux of this tradition is studying the differences among 'occupational' classes. But are occupational classes really social classes? Certainly not. They only build the economic basis on top of which similar interests can be developed. It is certainly more precise to talk of 'economic classes' rather than 'social classes', where individuals also share a collective identity and may ultimately become political actors (e.g. Kocka 1980).

Class schemata propose a representation of social stratification that go well beyond the widespread dichotomy between blue-collar and whitecollar occupations. This distinction is above all telling in the context of a manufacturing company where it differentiates between the shop floor where production workers are active and the office area where clerks, technicians and the management work. Outside the manufacturing world, implementing the dichotomy is less straightforward. The category of blue-collar workers is strongly associated with factory workers; other occupations characterised by harsh working conditions such as domestic service-once a widespread occupation among female workers-are more difficult to classify. There are also occupations that are neither blue-collar nor white-collar. One can think, for example, of workers in the transport sector, for example railway employees or tramway drivers. They do not perform their work in an office but are also not active in a production process. Precise definitions are often lacking and render the classification of occupations difficult. One should also mention that social security schemata are based on this dichotomy in some countries-especially in Germany. Variations in definitions may also reflect the development of social protection and struggles around it.

Complex class schemata-which require detailed lists of occupations based on open-format questions-are widespread in the literature. In political science, their use has been advocated since many years to study 
voting behaviour (e.g. Evans 1999a, 2000). However, it is astonishing how influential the blue-collar vs. white-collar distinction remains. It is not unusual for surveys to include closed-format questions where individuals are asked to place themselves in a categorisation derived from this dichotomy. Quite common is also to find data where pollsters have recoded respondents' occupations into a limited number of categories based on this distinction. This often occurs in surveys conducted in German-speaking countries, but it is also the case in some cross-national surveys (e.g. Eurobarometer surveys). These data render the prospect of using a sophisticated class schema difficult or imprecise (but see a careful attempt to construct the Erikson and Goldthorpe class schema using Eurobarometer data in Knutsen 2006: 17-23).

\section{Taking Politics Seriously: The Role of Political Parties in Class Mobilisation}

If one adopts a sociological perspective, one can analyse the extent to which classes display homogeneity in their political behaviour. If a class schema captures pertinent differences among classes, it is quite likely that classes will display some variation in their political preferences. Voting behaviour is therefore the product of the social divisions existing in a society. This approach was emphasised at the macro-level by Lipset and Rokkan (1967) in their analysis of the formation of party systems. They stressed that party systems in the 1960s reflected the social divisions at the time of the development of party systems in the early twentieth century. At the micro-level, the first explanations of voting behaviour emphasised the close connection between an individual's social position and his political preferences. Lazarsfeld and his team, who were pioneers in electoral research, stressed that 'a person thinks, politically, as he is, socially' (1944: 27). There is surely some determinism in this approach. Above all, it leaves little room for political actors or in any case does not primarily stress the role of politics. In this section, I would like to stress the importance of political actors who reinforce the salience of social class. We can only understand the transformation of social democracy if we try to integrate into the framework the extent to which parties mobilise their voters with a class-based appeal.

Political scientists have brought interesting distinctions to the fore and have proposed to complement the sociological approach in various ways. Peter Mair (1999) suggests a useful distinction between 'class voting' 
and 'class politics'. He makes this distinction in a volume dedicated to the study of class voting (Evans 1999b). According to Mair, class voting is a sociological approach to voting where the goal is to assess whether classes differ overall in their voting behaviour. The focus lies on the cohesiveness of classes, but less on the specific parties that classes choose and the reasons behind these choices. By contrast, class politics implies entering the realm of politics. The term refers more broadly to the various processes through which parties and interest organisations translate social conflicts into political conflicts. In order to understand the links between classes and parties, one needs, therefore, to get a sense of the representation of class interests by political parties.

The concept of 'cleavage' represents a useful tool to make a connection between sociological and political approaches. Mair again, together with Bartolini (1990), discusses this concept that links social structure to political order in detail. According to these authors, a cleavage is much more than a pure social division (a 'social cleavage'), which has no organisation at the political level, or a pure political division (a 'political cleavage'), which lacks a connection to the social structure. Bartolini and Mair articulate three components of a cleavage: (1) an empirical element that refers to social structure; (2) a normative element that refers to the values and beliefs shared by a group; (3) an organisational/behavioural component that refers to the interactions, institutions and organisations that develop as part of the cleavage (e.g. political parties or trade unions) (Bartolini and Mair 1990: 215-216). They propose limiting the use of the cleavage concept to divisions that include these three elements, which often reinforce each other. A purely socio-structural approach is therefore not enough to analyse the changes in class-based cleavages that are at the centre of this book. The research agenda outlined here consists in systematically investigating the interaction between social divisions and political actors.

A similar research agenda can be identified in other contributions. Przeworski and Sprague (1986) underline the importance of party strategies and actions in voting. They are particularly interested in social class and the development of class voting. The extent to which social class constitutes a defining element of voting must be thought of in close connection with political actors. Political parties are not passive actors but they actively shape the support they receive among social groups, according to these authors. The extent to which individuals vote on the basis of their social class not only depends on class structure but is also the 
result of the actions of political parties. The authors are therefore interested in social class in relation to the process of class formation (Sainsbury 1990).

The influence of political parties has not been at centre stage in research for a long time. It was seen as relatively natural that leftwing parties should articulate class interests. Workers would find a party supporting (at least to some extent) working-class interests in the political sphere. The idea that parties mobilise class was somehow implicit in the literature dedicated to class voting. However, the significant ideological mutations of social democracy over recent decades have shown that class-based appeal from the left cannot be taken for granted. When scholars started to engage in more depth with explanations of the decline in class-based voting behaviour, explanations involving political parties gained attraction (see Elff 2009).

The most recent attempt to think carefully about the role of political actors in class voting can be found in a book edited by Evans and De Graaf (2013). The authors propose a distinction between 'bottom-up' and 'top-down' explanations of the decline in class voting. The underlying idea of the 'bottom-up' approach is that if class voting declines it is because classes have become more heterogeneous as a result of processes of individualisation and fragmentation. This perspective, which has been dominant in the literature on the decline in class voting, for the authors represents only one side of the coin. It is also necessary to take into account how class differences are articulated by political actors and the political elite. Changes in class voting can therefore be driven by transformations of social classes themselves or by transformations of parties and the political elite who mobilise class differences. When adopting this view, class voting takes on a new light. Class voting is also likely to increase if political parties mobilise social classes more explicitly-the trend of class voting decline can be reversed (see also Evans and Tilley 2012).

An interesting empirical test of this new framework was conducted in Great Britain. 'Working on a new dataset on the period 1959-2006, Evans and Tilley (2012) show that most of the decline in class voting occurs at the end of the period under study. They identify a strong decline in class differences in the support for the Labour Party since the mid1990s. They also observe a considerable decrease in the 1960s and a smaller one between the 1970s and the beginning of the 1990s. The authors demonstrate that the growing heterogeneity of social classes (in terms of education, gender, income, etc.) does not explain their increasing 
proximity in party choice. It is only when the authors include the changes in the left-right positioning of political parties (and especially the move to the centre by the Labour Party in the 1990s) that they can explain the changes in class-party relationships. ${ }^{2}$

This perspective suggests that social democracy can lose its workingclass support due to political choices. At the same time, the approach also emphasises the capacity of social democracy to renew its appeal to its working-class electorate if it adopts a pertinent political strategy. My emphasis on 'politics' in this section reminds us of the capacity of parties to generate support among specific groups.

\section{Taking History Seriously: Social Democracy as a Workers' Party, But Not Only as Such}

The literature on class voting focuses on the existence of divisions in voting behaviour. However, instead of emphasising differences in voting behaviour between the working class and the middle class, it is possible to take a different perspective and emphasise proximities between some 'intermediate' classes and the working class. This section does not aim to deny the working-class character of social democracy or to deny the important differences in voting between social classes. Instead, the aim is to demonstrate that social democracy has not only sought to attract industrial workers but has simultaneously sought support among potentially allied groups. The aim is to reconcile the study of class voting with historical evidence pointing to the existence of complex class coalitions. In order to do this, one needs to depart from the dominant binary distinction between white-collar work and blue-collar work that surrounds much of the literature on social democracy.

From a historical perspective, it would be wrong to understand social democracy as a purely factory workers' movement. Certainly, social democracy benefited from the increasing concentration of the workforce in larger workplaces-a decisive element in the electoral strength of socialist parties (see Bartolini 2000; Pontusson 1995) —and the strong similarity in its working and living conditions in the heyday of industrialisation. However, social history accounts draw our attention to a strong diversity in terms of occupations, skills and origins among workers and attempts by the labour movement to build unity in this diversity (e.g. Thompson 1979; Noiriel 1986). In the nineteenth century, craft workers 
played a key role in the development of the labour movement and particularly in the formation of trade unions (Mommsen and Husung 1985). There were also intellectuals present in social democratic parties from the beginning. The leaders of social democratic parties themselves did not always have a working-class background, but often came from families from the petty or even the haute bourgeoisie.

It is also clear that several groups of lower-rank white-collar workers, or workers that were not easily classifiable as blue-collar or white-collar, already displayed sympathy for social democracy at the onset of the mobilisation of the labour movement. The proximity between the interests of factory workers and (often female) lower-level employees tends to be forgotten in studies that are based on the crude and imprecise blue-collar vs. white-collar distinction. Furthermore, public sector employees and especially workers in public infrastructure and services (railway workers and post office workers) have been prominent supporters of social democracy in many countries, notably thanks to a strong union density. Membership figures indicate an important presence of these workers and employees in the ranks of social democratic parties (e.g. Reynard 2013; Sühl 1988; Wicki 2007). Generally, rail unions have played a significant role in the labour movement and have critically contributed to the development of social democratic and labour parties in many countries (see Crompton 2009 on Great Britain; Bauer [1930] 1979 on Austria).

Furthermore, social democratic parties themselves had the ambition early on to appeal to other allied classes. In this respect, it is very interesting to read a text by Friedrich Engels from 1895. In the introduction to Karl Marx's The Class Struggles in France, Engels ([1895] 1977) is euphoric, enthusiastic about the strong electoral progression of the German Social Democratic Party (SPD) following the introduction of male universal suffrage. He saw the utilisation of universal suffrage by German workers as an example for the labour movements in other countries. He also estimated that by the end of the nineteenth century the SPD would be able to convince large parts of the middle class, including the petty bourgeoisie and small farmers. Of course, this thesis is strongly influenced by the idea that large parts of the middle class would become proletarianised. However, this shows very well the agenda of convincing segments beyond the industrial working class.

Political science accounts consider the relationship of social democracy with other potentially allied classes. In the 1960s, Kirchheimer (1966) 
observed the beginning of a radical transformation of social democracy. He considered the context of the post-war period to have created strong pressures on the functioning and principles of social democratic parties (and also of Christian Democratic parties). Trends towards a secularisation of society, the development of mass consumption and the weakening of divisions between social classes were leading parties to transform themselves into what he termed 'catch-all “people's" parties' (1966: 184). In his view, this new model of party organisation was supplanting that of the 'class-mass integration party' that had characterised social democracy throughout the first half of the twentieth century. Kirchheimer was interested not only in the electorate, but more largely in the ideological and organisational transformations parties were undergoing. Next to a deemphasis of the party's core clientele and a willingness to recruit voters from all segments of the population, he also analysed the transformation of social democracy as a weakening of party ideology, a strengthening of the top leadership, a downgrading of individual membership and access to various interest groups (Kirchheimer 1966: 20).

Kirchheimer's analysis is based on observations on several West European countries (including France, Italy and Great Britain), but the transformation of the German Social Democratic Party probably had an important influence on the development of the catch-all party thesis (see also Safran 2009). The SPD adopted a new manifesto in 1959 which marked a substantial ideological rupture. The Bad Godesberg Programme was no longer structured along a Marxist view of society and described the SPD as a people's party (Volkspartei) and no longer as a class-based party. Although Kirchheimer does not refer explicitly to the Bad Godesberg Programme in his essay, it is clear that the catch-all party thesis must be thought to be closely connected to it.

From the point of view of the demand side of voters, one can read the catch-all party model as successful recruitment of voters from all segments of the population. Instead of being heavily biased towards working-class voters, 'catch-all' social democracy thus represents a sort of mirror of the entire electorate. However, Kirchheimer's argument is more nuanced (Müller 1992: 190-191). Social democratic parties would not seek to convince all voters, but only those 'whose interests do not adamantly conflict' (Kirchheimer 1966: 186). He mentions the example of whitecollar workers and civil servants, two groups that could be targeted simultaneously with blue-collar workers without losing credibility. While Kirchheimer is known for having put forward the concept of the catch-all 
party, his idea of enlarging the electoral targets of social democracy is still to some extent compatible with the idea of social democracy as a workingclass movement. Later on, I will advance the term 'hybrid working-class party' to characterise the situation in which social democracy mobilises the working class and also allied classes.

In their well-known book Paper Stones on the history of electoral socialism, Przeworski and Sprague (1986) adopt a position diametrically opposed to that of Kirchheimer. A hybrid working-class party is not sustainable in the long run. Their argument is that an opening to other segments transforms the class character of social democracy and marks an end to its working-class character. More precisely, the two authors focus on the history of socialist parties. They observe a similar scenario in every country. Socialist parties grew larger, but their electoral progress stopped after a certain time. According to these authors, the main reason is that the expected proletarianisation of large segments of the population did not happen and workers never became a majority of the electorate. This element is of central importance in Przeworski and Sprague's work. The fact that workers do not constitute more than $50 \%$ of the electorate constrains socialist parties to look for allies outside the working class. This leads the authors to articulate the existence of an electoral dilemma for socialist parties. Socialist parties can either remain parties of the working class without reaching any parliamentary majority or obtain electoral majorities but with the risk of losing their working-class electorate with an appeal extended to other classes. Socialist parties as working-class parties are undeniably condemned to fail: either they remain small or they lose their working-class character.

\section{A Note: A 'Working-Class Party' Is More Than a Working-Class Electorate}

This book focuses on studying the electorate of social democracy. At this stage, it is essential to note that the idea of a 'working-class party' goes well beyond a working-class electorate. Historically, social democracy relies on a close connection among the electorate, the ideology and the movement. A working-class party means not only a party supported by workers but also a party that tries to improve the living conditions of workers. The ultimate goal is to achieve an emancipation of the working class that abolishes their dependency on the interests of capitalists. Moreover, historical contributions also note the existence of a close connection 
between social democracy and labour unions as part of a larger social movement, the labour movement.

The analysis in this book is focused primarily on the electorate, but there is a constant effort to put the transformation of the electorate in close connection with ideology and labour unions throughout the book. It is also important to emphasise this element given the new competition that social democracy faces among workers. From a demand-side perspective, one can observe that new parties attract votes from workers. However, if one follows the encompassing definition of a working-class party, it is difficult to put radical right parties in this category. Following the criteria of ideology and movement, radical right parties cannot be described as working-class parties. Their ideology is clearly opposite to the socialist ideology based on the emancipation of the working class. They also constantly attack the legitimacy of trade unions (see Mosimann et al. 2019).

\section{Using the Oesch Class Schema to Study the Transformation of Social Democracy}

It is necessary to have a class schema that is precise enough to capture the core electorate of social democracy - the industrial working classbut flexible enough to analyse the creation of various class coalitions that are likely to change over time. The new class schema developed by Oesch (2006) perfectly fits these two criteria. It allows a precise operationalisation of lower non-manual classes and also for diverse segments of the salaried middle classes to be taken into account-a new and growing potential for social democracy.

The Oesch class schema represents an alternative to the Erikson and Goldthorpe (1992) class schema-also known under the abbreviation EGP - which is predominantly used in the class voting literature. EGP was conceived for societies in which employment in the manufacturing sector still constitutes an important share of total employment. By contrast, the Oesch class schema represents the most ambitious attempt to take into account changes in employment structure that have occurred in recent decades, such as the decrease in manual employment and occupational upgrading.

In a similar vein to the EGP class schema, the Oesch class schema (represented in Table 2.1) includes a vertical dimension that distinguishes more or less advantageous positions in the labour market. Additionally, 
Table 2.1 Oesch's 8-class schema with representative occupations and the average size of classes in the 1970s and in 2010-2015

\begin{tabular}{|c|c|c|c|}
\hline $\begin{array}{l}\text { Interpersonal service } \\
\text { logic }\end{array}$ & Technical work logic & $\begin{array}{l}\text { Organisational work } \\
\text { logic }\end{array}$ & $\begin{array}{l}\text { Independent work } \\
\text { logic }\end{array}$ \\
\hline $\begin{array}{l}\text { Socio-cultural } \\
(\text { semi-) professionals } \\
8 \% \rightarrow 13 \%\end{array}$ & $\begin{array}{l}\text { Technical (semi- }) \\
\text { professionals } \\
4 \% \rightarrow 7 \%\end{array}$ & $\begin{array}{l}\text { (Junior) managers } \\
11 \% \rightarrow 17 \%\end{array}$ & $\begin{array}{l}\text { Large employers } \\
\text { and self-empl. } \\
\text { professionals } \\
2 \% \rightarrow 3 \%\end{array}$ \\
\hline Medical doctors & Engineers & Administrators & Entrepreneurs \\
\hline Teachers & Architects & Consultants & Lawyers (self-empl.) \\
\hline Social workers & IT-specialists & Accountants & \\
\hline Service workers & Production workers & Clerks & Small business \\
\hline $14 \% \rightarrow 20 \%$ & $31 \% \rightarrow 16 \%$ & $17 \% \rightarrow 13 \%$ & $\begin{array}{l}\text { owners } \\
13 \% \rightarrow 11 \%\end{array}$ \\
\hline Waiters & Mechanics & Secretaries & Shop owners \\
\hline Nursing aids & Carpenters & Receptionists & Independent artisans \\
\hline Shop assistants & Assemblers & Mail clerks & Farmers \\
\hline
\end{tabular}

Source Own calculations based on the Political Action Survey and the European Social Survey (see Chapters 3 and 4 for the detailed sources). Averages for six countries (Austria, France, Germany, Great Britain, the Netherlands and Switzerland). Based on respondents' class positions

and this is where it departs most from the EGP class schema, it also includes a horizontal dimension which is based on different 'work logics'. Starting with the importance of daily work experiences in shaping interests and loyalties, Oesch distinguishes between three different work logics for employees: the 'organisational work logic', the 'technical work logic' and the 'interpersonal work logic'. A fourth work logic, the 'independent work logic' applies to employers and the self-employed. Within the salaried middle classes, the horizontal dimension permits a distinction among managers (included in the 'organisational work logic'), sociocultural professionals (included in the 'interpersonal work logic') and technical professionals (included in the 'technical work logic'). Managers are the group that is closest to the interests of employers, while sociocultural professionals are the most remote (see Kriesi 1998).

The horizontal distinctions are not limited to the salaried middle classes but apply to all positions in the labour market. This allows the contours of the working class to be enlarged to the 'new proletariat' in the service 
sector. In this schema, the production workers included in the 'technical work logic' form the core of the manual working class. The service workers included in the 'interpersonal work logic' represent most clearly the 'new proletariat' in the services. An additional category is composed of office workers, which take the lower positions in the 'organisational work logic'. Unlike the EGP class schema, all these classes have a similar hierarchical position.

The most sophisticated version of the Oesch class schema includes 17 classes that can be merged in order to form more parsimonious class schemas. In this book, the 8-class version is used, which groups together the two classes with the lowest skill level and the two classes with the highest level. This means that unskilled workers are grouped together with skilled workers (at the bottom) and that associate professionals are grouped together with professionals (at the top). This merging is useful from a practical point of view. Since occupational classifications change over time, it is easier to find conversions when dealing with a smaller number of categories. Crucially, it is meaningful from a theoretical point of view. Access to higher education becomes the decisive criteria on the vertical dimension. The disadvantage of this merging is that class differences appear to be more flat on the vertical dimension, in comparison with other class schemata.

Table 2.1 indicates the average size of the eight classes in the 1970s and the 2000s-2010s in six Western European countries. Production workers represented almost a third of the population eligible to vote and were by far the largest group in the 1970s. In the more recent period, they only form $16 \%$ of the population, a proportion equivalent to that of managers and slightly smaller than that of service workers.

Three variables are needed to construct the Oesch' class schema (the 8-class version): occupation; status of employment; and number of employees, in order to distinguish large employers from small business owners. Information is derived from the current position of an individual in the labour market and from the past position if the respondent is retired or unemployed. Concerning occupation, the schema is based on the International Standard Classification of Occupations (ISCO) developed by the International Labour Organisation (ILO). More precisely, the schema was initially developed on the basis of the 1988 classification (ISCO-88) at its most detailed level (4-digits). It is possible to find translations with the older version of the classification (ISCO-68) and the newer version (ISCO-08). These are sometimes present in the surveys used in this book. 
In some cases, instead of the international classification, national classifications of occupations are available in surveys. Again, it is possible to translate them into ISCO codes or directly into the eight classes.

\section{Notes}

1. Next to the chapters included in the edited volume by Evans and De Graaf (2013), several other studies have tested some top-down or supply-side hypotheses (e.g. Arès 2017; Langsxther 2019; Rennwald and Evans 2014; Vestin 2019).

2. Relatively similar effects on the move to the centre by social democratic parties can be found in a study by Arndt (2013). The author focuses on Third Way welfare state reforms conducted by social democratic governments at the end of the 1990s in four West European countries. He also demonstrates a negative impact of these reforms on working-class support in Denmark, Germany and Great Britain.

\section{REFERENCES}

Arès, M. (2017). A New Working Class? A Comparative and a Longitudinal Approach to Class-Politics in Post-Industrial Societies. Doctoral Thesis, Department of Political and Social Sciences, European University Institute.

Arndt, C. (2013). The Electoral Consequences of Third Way Welfare State Reforms. Amsterdam: Amsterdam University Press.

Bauer, O. ([1930] 1979). Es wird nicht gelingen, die Kraft der Eisenbahner zu brechen (Arbeiter-Zeitung, Wien, 14 December 1930). In O. Bauer (Ed.), Otto-Bauer-Werkausgabe Band I (pp. 237-238). Wien: Europa Verlag.

Bartolini, S. (2000). The Political Mobilization of the European Left, 1860-1980: The Class Cleavage. Cambridge: Cambridge University Press.

Bartolini, S., \& Mair, P. (1990). Identity, Competition, and Electoral Availability: The Stabilisation of European Electorates, 1885-1985. Cambridge: Cambridge University Press.

Crompton, G. (2009). Lines of Division: Railway Unions and Labour, 1900-39. In M. Worley (Ed.), The Foundations of the British Labour Party. Identities, Cultures and Perspectives, 1900-39 (pp. 37-56). London: Routledge.

Elff, M. (2009). Social Divisions, Party Positions, and Electoral Behaviour. Electoral Studies, 28, 297-308.

Engels, F. ([1895] 1977). Einleitung zu Karl Marx' "Klassenkämpfe in Frankreich 1848 bis 1850". In K. Marx \& F. Engels (Eds.), Marx Engels Werke 22. Berlin: Karl Dietz Verlag. 
Erikson, R., \& Goldthorpe, J. H. (1992). The Constant Flux: A Study of Class Mobility in Industrial Societies. Oxford: Clarendon Press.

Evans, G. (1999a). Class Voting: From Premature Obituary to Reasoned Appraisal. In G. Evans (Ed.), The End of Class Politics? Class Voting in Comparative Context (pp. 1-20). Oxford: Oxford University Press.

Evans, G. (Ed.). (1999b). The End of Class Politics? Oxford: Oxford University Press.

Evans, G. (2000). The Continued Significance of Class Voting. Annual Review of Political Science, 3(1), 401-417.

Evans, G., \& De Graaf, N. D. (Eds.). (2013). Political Choice Matters: Explaining the Strength of Class and Religious Cleavages in Cross-National Perspective. Oxford: Oxford University Press.

Evans, G., \& Mills, C. (2000). In Search of the Wage-Labour/Service Contract: New Evidence on the Validity of the Goldthorpe Class Schema. The British Journal of Sociology, 51(4), 64l-661.

Evans, G., \& Tilley, J. (2012). How Parties Shape Class Politics: Explaining the Decline of the Class Basis of Party Support. British Journal of Political Science, 42(01), 137-161.

Goldthorpe, J. H., \& McKnight, A. (2006). The Economic Basis of Social Class. In S. L. Morgan, D. B. Grusky, \& G. S. Fields (Eds.), Mobility and Inequality: Frontiers of Research from Sociology and Economics (pp. 109-136). Stanford: Stanford University Press.

Kirchheimer, O. (1966). The Transformation of the Western European Party Systems. In J. Lapalombara \& M. Weiner (Eds.), Political Parties and Political Development (pp. 177-200). Princeton: Princeton University Press.

Knutsen, O. (2006). Class Voting in Western Europe: A Comparative Longitudinal Study. Lanham, MD: Lexington Books.

Kocka, J. (1980). The Study of Social Mobility and the Formation of the Working Class in the 19th Century. Le Mouvement Social, 111, 97-117.

Kriesi, H. (1998). The Transformation of Cleavage Politics: The 1997 Stein Rokkan Lecture. European Journal of Political Research, 33(2), 165-185.

Langsxther, P. E. (2019). Class Voting and the Differential Role of Political Values: Evidence from 12 West-European Countries. Journal of Elections, Public Opinion and Parties, 29(1), 125-142.

Lazarsfeld, P. F., Berelson, B., \& Gaudet, H. (1944). The People's Choice: How the Voter Makes Up His Mind in a Presidential Campaign. New York: Columbia University Press.

Lipset, S. M., \& Rokkan, S. (1967). Cleavage Structures, Party Systems, and Voter Alignments: An Introduction. In S. M. Lipset \& S. Rokkan (Eds.), Party Systems and Voter Alignments: Cross-national Perspectives (pp. 1-64). New York: The Free Press. 
Mair, P. (1999). Critical Commentary: Four Perspectives on the End of Class Politics. In G. Evans (Ed.), The End of Class Politics? Class Voting in Comparative Context (pp. 308-322). Oxford: Oxford University Press.

Mommsen, W. J., \& Husung, H. (Eds.). (1985). The Development of Trade Unionism in Great Britain and Germany. New York: Routledge.

Mosimann, N., Rennwald, L., \& Zimmermann, A. (2019). The Radical Right, the Labour Movement and the Competition for the Workers' Vote. Economic and Industrial Democracy, 40(1), 65-90.

Müller, W. C. (1992). The Catch-All Party Thesis and the Austrian Social Democrats. German Politics, 1(2), 181-199.

Noiriel, G. (1986). Les ouvriers dans la société française: XIXe-XXe siècle. Paris: Seuil.

Oesch, D. (2006). Redrawing the Class Map: Stratification and Institutions in Britain, Germany, Sweden and Switzerland. London: Palgrave Macmillan.

Pontusson, J. (1995). Explaining the Decline of European Social Democracy: The Role of Structural Economic Change. World Politics, 47(4), 495-533.

Przeworski, A., \& Sprague, J. (1986). Paper Stones: A History of Electoral Socialism. Chicago: University of Chicago Press.

Rennwald, L., \& Evans, G. (2014). When Supply Creates Demand: Social Democratic Party Strategies and the Evolution of Class Voting. West European Politics, 37(5), 1108-1135.

Reynard, M. (2013). Les débuts du Parti socialiste valaisan (1900-1929). Sion: Parti socialiste du Valais Romand.

Therborn, G. (1995). European Modernity and Beyond: The Trajectory of European Societies, 1945-2000. London: Sage.

Thompson, E. P. (1979). The Making of the English Working Class. Harmondsworth: Penguin Books.

Safran, W. (2009). The Catch-All Party Revisited: Reflections of a Kirchheimer Student. Party Politics, 15(5), 543-554.

Sainsbury, D. (1990). Party Strategies and the Electoral Trade-Off of Class-Based Parties. European Journal of Political Research, 18(1), 29-50.

Sühl, K. (1988). SPD und öffentlicher Dienst in der Weimarer Republik. Wiesbaden: VS Verlag für Sozialwissenschaften.

Vestin, E. (2019). The Decline of Class Voting in Sweden 1968-2014. Reconsiderations, Explanations, and the Role of the New Middle Class. Doctoral Thesis, Department of Political Science, University of Gothenburg.

Wicki, J. (2007). "On ne monte pas sur les barricades pour réclamer le frigidaire pour tous": Histoire sociale et politique du parti socialiste vaudois (1945-1971). Lausanne: Ed. Antipodes. 
Open Access This chapter is licensed under the terms of the Creative Commons Attribution 4.0 International License (http://creativecommons.org/licenses/ by $/ 4.0 /$ ), which permits use, sharing, adaptation, distribution and reproduction in any medium or format, as long as you give appropriate credit to the original author(s) and the source, provide a link to the Creative Commons license and indicate if changes were made.

The images or other third party material in this chapter are included in the chapter's Creative Commons license, unless indicated otherwise in a credit line to the material. If material is not included in the chapter's Creative Commons license and your intended use is not permitted by statutory regulation or exceeds the permitted use, you will need to obtain permission directly from the copyright holder.

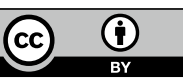

